\title{
Graphene oxide-silver nanocomposite as a promising biocidal agent against methicillin- resistant Staphylococcus aureus
}

This article was published in the following Dove Press journal:

International Journal of Nanomedicine

2 November 2015

Number of times this article has been viewed

\author{
Ana Carolina Mazarin de \\ Moraes' \\ Bruna Araujo Lima ${ }^{2}$ \\ Andreia Fonseca de Faria' \\ Marcelo Brocchi ${ }^{2}$ \\ Oswaldo Luiz Alves' \\ 'Laboratory of Solid State Chemistry, \\ Institute of Chemistry, University of \\ Campinas, Campinas, São Paulo, Brazil; \\ ${ }^{2}$ Department of Genetics, Evolution \\ and Bioagents, Institute of Biology, \\ University of Campinas, Campinas, \\ São Paulo, Brazil
}

Background: Methicillin-resistant Staphylococcus aureus (MRSA) has been responsible for serious hospital infections worldwide. Nanomaterials are an alternative to conventional antibiotic compounds, because bacteria are unlikely to develop microbial resistance against nanomaterials. In the past decade, graphene oxide (GO) has emerged as a material that is often used to support and stabilize silver nanoparticles (AgNPs) for the preparation of novel antibacterial nanocomposites. In this work, we report the synthesis of the graphene-oxide silver nanocomposite (GO-Ag) and its antibacterial activity against relevant microorganisms in medicine.

Materials and methods: GO-Ag nanocomposite was synthesized through the reduction of silver ions $\left(\mathrm{Ag}^{+}\right)$by sodium citrate in an aqueous GO dispersion, and was extensively characterized using ultraviolet-visible absorption spectroscopy, X-ray diffraction, thermogravimetric analysis, X-ray photoelectron spectroscopy, and transmission electron microscopy. The antibacterial activity was evaluated by microdilution assays and time-kill experiments. The morphology of bacterial cells treated with GO-Ag was investigated via transmission electron microscopy. Results: AgNPs were well distributed throughout GO sheets, with an average size of $9.4 \pm 2.8 \mathrm{~nm}$. The GO-Ag nanocomposite exhibited an excellent antibacterial activity against methicillinresistant S. aureus, Acinetobacter baumannii, Enterococcus faecalis, and Escherichia coli. All $(100 \%)$ MRSA cells were inactivated after 4 hours of exposure to GO-Ag sheets. In addition, no toxicity was found for either pristine GO or bare AgNPs within the tested concentration range. Transmission electronic microscopy images offered insights into how GO-Ag nanosheets interacted with bacterial cells.

Conclusion: Our results indicate that the GO-Ag nanocomposite is a promising antibacterial agent against common nosocomial bacteria, particularly antibiotic-resistant MRSA. Morphological injuries on MRSA cells revealed a likely loss of viability as a result of the direct contact between bacteria and the GO-Ag sheets.

Keywords: graphene oxide, silver nanoparticles, graphene oxide-silver nanocomposite, antibacterial agent, MRSA, Escherichia coli

\section{Introduction}

Antibiotic-resistant microorganisms are a growing global concern. In particular, methicillin-resistant Staphylococcus aureus (MRSA) has overcome a variety of antibiotics in the past few decades, and its dissemination has led to serious hospitalacquired infections worldwide. ${ }^{1,2}$ MRSA can easily spread in hospitals, health care facilities, and community environments. Transmission of the microbe occurs mostly through direct contact with wounds, respiratory and feeding tubes, urinary catheters, and indwelling devices. ${ }^{3}$ de Moraes; Oswaldo Luiz Alves

Laboratory of Solid State Chemistry,

Institute of Chemistry, University of

Campinas, PO Box 6154, 13083-970

Campinas, São Paulo, Brazil

Tel +551935213394

$\mathrm{Fax}+551935213023$

Email anacmmo@gmail.com;

oalves@iqm.unicamp.br 
According to the World Health Organization (WHO), approximately $5 \%-10 \%$ of patients throughout the world will face some acquired nosocomial infection during hospitalization. ${ }^{4}$ The US Centers for Disease Control and Prevention has estimated that in the US alone, the mortality rate due to infections may reach 3.1 deaths for every 9.7 hospitalized patients. ${ }^{5}$ In Latin America, including countries such as Brazil and Argentina, the incidence of MRSA has reached $67 \%$ of all $S$. aureus-related infections. ${ }^{6}$

MRSA is especially resistant toward $\beta$-lactam antibiotics (penicillin, cephalosporin, and carbapenems), ${ }^{7}$ and its drug-resistance mechanism is mediated by the production of $\beta$-lactamase enzymes and the mec $A$ gene, which encodes the penicillin-binding protein PBP2a. ${ }^{8}$ These infections cost health care systems billions of dollars, and there is an expectation that the number of infections will continuously increase over the years. ${ }^{9}$ Thus, the emergence of antibiotic-resistant bacteria represents a serious problem that could be overcome by the development of novel antimicrobial agents.

Nanomaterials are an alternative approach to treating and mitigating infections caused by resistant bacteria. Microbial cells are unlikely to develop resistance to nanomaterials, because they exert toxicity through different mechanisms than conventional antibiotics. Antimicrobial nanomaterials such as zinc oxide, titanium oxide, and single-walled carbon nanotubes may offer several advantages due to their unique physicochemical properties and high surface areas. ${ }^{10}$ Specifically, graphene oxide (GO) sheets are composed of oxidized graphene sheets bearing oxygen-containing functional groups such as epoxy, carboxyl, carbonyl, and hydroxyl groups. GO is highly hydrophilic, yields stable dispersions in water, and can be easily produced on a large scale. In addition, the oxygenated groups enable the straightforward chemical functionalization of GO sheets via covalent and non-covalent interactions. ${ }^{11}$ Graphene has been extensively used for several biological applications including bioimaging, ${ }^{12}$ tissue engineering, ${ }^{13}$ drug delivery, ${ }^{14}$ and regenerative medicine. ${ }^{15}$ Furthermore, the effects of graphene on mammalian stem, ${ }^{16}$ cancerous, ${ }^{17}$ and bacterial cells ${ }^{18}$ have been explored.

Graphene-based nanomaterials have drawn much attention as excellent platforms to which silver nanoparticles (AgNPs) can be anchored for the production of antimicrobial nanocomposites. ${ }^{19-25}$ AgNPs are widely known because of their outstanding antimicrobial toxicity in comparison to their bulk counterparts. ${ }^{26}$ However, AgNPs present a strong tendency to aggregate in aqueous solutions, leading to a decrease in biocidal activity. ${ }^{26}$ Although the use of surfactants can maintain the colloidal stability of AgNPs, they can also hinder the particles' surface oxidation. As a consequence, a reduced toxicity to bacterial cells might be observed as a result of the decreased rate of $\mathrm{Ag}^{+}$ion release. ${ }^{27}$ Therefore, these distinct and attractive features make GO an appealing platform for building novel antibacterial nanocomposites. GO sheets act as support layers to stabilize and to prevent AgNPs from aggregating, allowing a more controlled release of $\mathrm{Ag}^{+}$ions and an enhanced antimicrobial activity.

In the current study, we demonstrated the synthesis of GO-silver nanocomposite (GO-Ag) through the reduction of $\mathrm{Ag}^{+}$ions by sodium citrate $\left(\mathrm{Na}_{3} \mathrm{C}_{6} \mathrm{H}_{5} \mathrm{O}_{7}\right)$ in an aqueous GO dispersion. These nanocomposites exhibited a broadspectrum of antibacterial activity and a noticeable toxicity to antibiotic-resistant MRSA. We also investigated the interaction between GO-Ag sheets and bacterial cells via transmission electron microscopy (TEM). To the best of our knowledge, this is the first report providing evidence of how GO-Ag nanocomposites interact with MRSA cells. Our results indicate that GO-Ag nanocomposites are promising antibacterial agents. These nanocomposites may possibly be used as a platform for the development of novel materials that are able to mitigate microbial proliferation in biomedical devices and hospital facilities.

\section{Materials and methods Materials and chemicals}

Natural graphite powder (98.0\%) was purchased from Synth (Diadema, Brazil) and was used as received. Potassium permanganate $\left(\mathrm{KMnO}_{4}, 99.0 \%\right)$, sulfuric acid $\left(\mathrm{H}_{2} \mathrm{SO}_{4}\right.$, 95.0\%-98.0\%), hydrochloric acid ( $\mathrm{HCl}, 36.5 \%-38.0 \%$ ), hydrogen peroxide $\left(\mathrm{H}_{2} \mathrm{O}_{2}, 30.0 \%\right)$, and $\mathrm{Na}_{3} \mathrm{C}_{6} \mathrm{H}_{5} \mathrm{O}_{7}(99.0 \%)$ were also obtained from Synth. Phosphorous pentoxide $\left(\mathrm{P}_{2} \mathrm{O}_{5}, 98.0 \%\right)$, potassium persulfate $\left(\mathrm{K}_{2} \mathrm{~S}_{2} \mathrm{O}_{8}, 99.0 \%\right)$, and silver nitrate $\left(\mathrm{AgNO}_{3}, \geq 99.0 \%\right)$ were provided by SigmaAldrich Co (St Louis, MO, USA). The Mueller-Hinton medium for bacterial cultivation was purchased from Becton, Dickinson and Company (Franklin Lakes, NJ, USA). The deionized (DI) water used in all experiments was supplied by a Milli- ${ }^{\circledR}$ purification system (EMD Millipore, Billerica, MA, USA). All chemicals were analytical grade.

\section{Synthesis of GO}

Single-layered GO sheets were synthesized by the modified Hummers' method. ${ }^{28}$ Briefly, graphite was pretreated to ensure complete oxidation. Natural graphite powder $(1.0 \mathrm{~g})$ was placed into an $80^{\circ} \mathrm{C}$ solution of concentrated $\mathrm{H}_{2} \mathrm{SO}_{4}(4.4 \mathrm{~mL}), \mathrm{K}_{2} \mathrm{~S}_{2} \mathrm{O}_{8}(0.8 \mathrm{~g})$ and $\mathrm{P}_{2} \mathrm{O}_{5}(0.8 \mathrm{~g})$. The dark blue mixture was kept on a hotplate under magnetic stirring 
for 4.5 hours. Shortly afterward, heating was stopped, and the mixture was diluted with DI water $(170 \mathrm{~mL})$ and was left overnight. On the following day, the mixture was filtered using a $0.22 \mu \mathrm{m}$ polyvinylidene fluoride membrane (Millipore $^{\circledR}$; EMD Millipore) and was washed with DI water until the filtrate reached neutral $\mathrm{pH}$. The dark, isolated solid was dried in air overnight at room temperature.

For the oxidation procedure, the pretreated graphite was added slowly into a chilled flask at $0^{\circ} \mathrm{C}$ containing concentrated $\mathrm{H}_{2} \mathrm{SO}_{4}(40 \mathrm{~mL}) . \mathrm{KMnO}_{4}(5.0 \mathrm{~g})$ was gradually added over 15-20 minutes, and the temperature was controlled to not exceed $10^{\circ} \mathrm{C}$. The ice bath was removed, and the resultant dark brown-purple mixture was allowed to react at $35^{\circ} \mathrm{C}$ for 2 hours. DI water $(77 \mathrm{~mL})$ was then added in small aliquots, and an ice bath was used to maintain the temperature below $50^{\circ} \mathrm{C}$. After the water addition, the mixture was kept under continuous stirring for an additional 2 hours. At that point, more DI water $(230 \mathrm{~mL})$ was introduced into the flask. Immediately afterward, $30 \% \mathrm{H}_{2} \mathrm{O}_{2}(4 \mathrm{~mL})$ was added, resulting in a bright yellow mixture that was allowed to settle for 2 days. The mixture was decanted, and the clear supernatant was removed. The remaining mixture was purified by centrifugation and was washed with $10 \% \mathrm{HCl}(500 \mathrm{~mL})$, followed by DI water, to remove metal ions and acid, respectively. The product was then suspended in DI water to give a stable, viscous brown dispersion, which was dialyzed for 10 days to remove residual salts (Fisherbrand ${ }^{\mathrm{TM}}$ dialysis tubing, 12,000-14,000 Da; Thermo Fisher Scientific, Waltham, MA, USA). The resulting homogeneous graphite oxide dispersion was lyophilized and was stored in a sealed vessel. GO suspensions were obtained by dispersing the product in water followed by sonication in an ultrasound bath (Cole-Parmer 8891).

\section{Synthesis of GO-Ag}

GO sheets were functionalized with AgNPs using a modified Turkevich method. ${ }^{19,29}$ For this procedure, a colloidal dispersion of GO was prepared by dispersing $6.25 \mathrm{mg}$ of GO in $20 \mathrm{~mL}$ of DI water followed by sonication in an ultrasound bath for 30 minutes. Next, $8.4 \mathrm{mg}$ of $\mathrm{AgNO}_{3}$ was dissolved in $20 \mathrm{~mL}$ DI water and then mixed with the previous GO dispersion. This mixture was sonicated for an additional 30 minutes and was transferred to a two-neck round-bottom flask. The AgNPs were produced using $\mathrm{Na}_{3} \mathrm{C}_{6} \mathrm{H}_{5} \mathrm{O}_{7}$ as a reducing agent. The dispersion containing $\mathrm{GO}$ and $\mathrm{AgNO}_{3}$ was heated at reflux, and as soon as it began to boil, $10 \mathrm{~mL}$ of a $1.0 \times 10^{-3} \mathrm{~mol} \mathrm{~L}^{-1} \mathrm{Na}_{3} \mathrm{C}_{6} \mathrm{H}_{5} \mathrm{O}_{7}$ solution was added dropwise. The reaction was maintained for $50 \mathrm{~min}$ at $130^{\circ} \mathrm{C}$. The color of the solution slowly turned black-green, indicating the formation of the GO-Ag nanocomposite. The GO-Ag was dialyzed for 2 days to remove residual salts (Fisherbrand dialysis tubing 12,000-14,000 Da) and stored in a sealed vessel protected from light.

\section{Characterization of GO and GO-Ag}

The physicochemical characterization of GO and GO-Ag was performed using several techniques. Primarily, ultraviolet-visible (UV-vis) spectroscopy was carried out using a Shimadzu UV-1650PC spectrometer. X-ray diffraction (XRD) analysis was conducted using a Shimadzu XRD-700 diffractometer with $\mathrm{CuK} \alpha \mathrm{X}$-ray radiation $(\lambda=1.54056 \AA$, $40 \mathrm{kV}, 5^{\circ}<2 \theta,<80^{\circ}$ with a scan rate of $\left.2^{\circ} \mathrm{min}^{-1}\right)$. Thermogravimetric analysis (TGA) was performed using a thermogravimetric analyzer (SDTQ600; TA Instruments, New Castle, DE, USA; $10^{\circ} \mathrm{C} \mathrm{min}^{-1}$, synthetic air flow rate of $100 \mathrm{~mL} \mathrm{~min}^{-1}$ ). X-ray photoelectron spectroscopy (XPS) spectra were obtained using a K-Alpha X-ray photoelectron spectrometer (Thermo Fisher Scientific). Fourier transform infrared spectroscopy (FTIR) spectra were recorded using an MB B100 spectrometer (ASEA Brown Boveri, Zürich, Switzerland; potassium bromide pellet). Raman spectroscopy measurements were performed on a T64000 (Horiba, Kyoto, Japan) with an argon ion laser set to an excitation wavelength of $514 \mathrm{~nm}$. The morphology of GO and GO-Ag nanocomposite was observed by TEM (LIBRA 120, accelerating voltage of $120 \mathrm{kV}$; Zeiss International, Oberkochen, Germany).

\section{Evaluation of antibacterial activity}

The antibacterial activity of GO and GO-Ag was evaluated by microdilution assays, as described by the Clinical and Laboratory Standards Institute (CLSI). ${ }^{30}$ To determine the minimal inhibitory concentration (MIC) and minimal bactericidal concentration (MBC), Gram-positive strains including S. aureus N315 (MRSA), kindly provided by Professor Dr Keiichi Hiramatsu (Department of Bacteriology, Faculty of Medicine, Juntendo University, Tokyo, Japan), ${ }^{31}$ S. aureus ATCC 29213 (standard CLSI); Enterococcus faecalis (ATCC 29212); the Gram-negative strains Escherichia coli (ATCC 25922) and Acinetobacter baumannii (ATCC 19606), both kindly provided by the Oswaldo Cruz Foundation (Fiocruz, Rio de Janeiro, Brazil); Salmonella enterica Typhimurium LT2 (kindly provided by Professor Dr Roy Curtiss III, the Biodesign Institute, Arizona State University, Tempe, AZ, USA); and Pseudomonas aeruginosa (ATCC 27853) were used as model microorganisms.

For the MIC determination, the strains were cultivated in Mueller-Hinton agar plates incubated at $37^{\circ} \mathrm{C}$ for 24 hours 
to obtain isolated colonies. The cells were suspended in a saline solution $(\mathrm{NaCl}, 0.85 \% \mathrm{w} / \mathrm{v})$, and the optical density $\left(\mathrm{OD}_{600 \mathrm{~nm}}\right)$ of the suspension was adjusted to 0.5 , according to the McFarland scale $\left(1.5 \times 10^{8}\right.$ colony-forming units per milliliter [CFU $\left.\mathrm{mL}^{-1}\right]$ ). The bacterial suspensions were diluted with Mueller-Hinton broth and were distributed in a 96-well plate to reach a cellular concentration of $1.0 \times 10^{5}$ $\mathrm{CFU} /$ well. Each well was exposed to different concentrations of GO and GO-Ag nanomaterials (from 60 to $1.0 \mu \mathrm{g} \mathrm{mL}^{-1}$ ). The plates were incubated at $37^{\circ} \mathrm{C}$, and the bacterial growth was observed after 18 hours. The MIC was considered as the lowest nanomaterial concentration where no bacterial growth was visualized. To determine the MBC values, the well plates were incubated under identical conditions for 24 hours. Then, the bacterial suspension in each well was collected and was plated on Mueller-Hinton Petri dishes. The Mueller-Hinton agar plates were incubated at $37^{\circ} \mathrm{C}$, and the bacterial growth was observed after 24 hours.

\section{Time-kill curves experiment}

To evaluate the antibacterial activity of GO-Ag nanocomposite as a function of time, we carried out time-kill experiments. MRSA and E. coli ATCC 25922 (standard CLSI) were used as model microorganisms. The cultivation of bacteria was performed as previously described in Evaluation of antibacterial activity section. MRSA and E. coli were exposed to GO-Ag concentrations at their MICs, which were both equivalent to $15 \mu \mathrm{g} \mathrm{mL} \mathrm{m}^{-1}$. The bacterial suspensions were then incubated in a rotatory shaker at $37^{\circ} \mathrm{C}$ and $200 \mathrm{rpm}$. A $100 \mu \mathrm{L}$ aliquot of the bacterial suspension was withdrawn from each cavity at different incubation times $(0,2,4,6,8$, 10,12 , and 24 hours) and was serially diluted (1:10) in saline solution $(0.85 \% \mathrm{w} / \mathrm{v})$. Next, $25 \mu \mathrm{L}$ of the diluted samples were plated on Mueller-Hinton media and incubated at $37^{\circ} \mathrm{C}$ for 12 hours. The number of bacterial colonies was counted and expressed in CFU $\mathrm{mL}^{-1}$. A control was carried out without the addition of the biocidal GO-Ag nanocomposite. Another control was performed using the GO sample at the same concentration used for the GO-Ag nanocomposite. All the tests were carried out in triplicate.

\section{TEM imaging of E. coli and MRSA cells after treatment with GO-Ag nanocomposite}

Initially, bacterial cultivation was conducted as described in the "Evaluation of antibacterial activity" section. The bacterial suspensions were diluted in Mueller-Hinton broth to a density of $1.0 \times 10^{5} \mathrm{CFU} \mathrm{mL} \mathrm{m}^{-1}$ and were incubated for
3 hours. Then, each strain was treated with GO-Ag nanocomposite at the MIC concentration $\left(15 \mu \mathrm{g} \mathrm{mL}^{-1}\right)$ for 2 hours. Negative controls were carried out without the addition of GO-Ag (untreated samples). An hour later, the suspensions were centrifuged for 10 minutes, and bacterial cells were collected and fixed with 3\% glutaraldehyde solution ( $\mathrm{pH} 7.4$ ) for 2 hours. The samples were centrifuged once more, and the cell pellets were washed three times with $0.1 \mathrm{~mol} \mathrm{~L}^{-1}$ phosphate-buffered saline (PBS, pH 7.4) solution. The cells were fixed with $1 \%$ osmium tetroxide $\left(\mathrm{OsO}_{4}\right)$ for 1 hour, and then washed twice with a PBS solution. After fixation, the cells were concentrated by centrifugation and treated with a few drops of a 1.5\% agarose solution. Subsequently, the cells were dehydrated with ethanol at increasing concentrations: $50 \%, 70 \%$, and $90 \%$ for 15 minutes each. To remove the residual ethanol, the cell pellet was treated initially with a mixture of ethanol/polypropylene oxide (1:1) for 15 minutes, followed by pure polypropylene oxide for 15 minutes, polypropylene oxide/resin (1:1) for 4 hours, and pure epoxy resin (Epon Resin 812; Electron Microscopy Sciences, Hatfield, PA, USA) overnight.

The cells were embedded in epoxy resin for 72 hours and were placed in an oven for polymerization. After material trimming, ultrathin sections were cut using an ultramicrotome (Leica Ultracut UCT; Leica Microsystems, Wetzlar, Germany). The sections were stained with $4 \%$ uranyl acetate for 30 minutes and $0.3 \%$ lead citrate for 3 minutes and were then transferred to uncoated copper grids and examined in a Zeiss LEO 902 transmission electron microscope (Zeiss International) operating at an accelerating voltage of $60 \mathrm{kV}$.

\section{Results \\ Physicochemical characteristics of GO and GO-Ag nanocomposite}

GO-Ag nanocomposite was prepared using $\mathrm{Na}_{3} \mathrm{C}_{6} \mathrm{H}_{5} \mathrm{O}_{7}$ as a reducing agent. The resulting stable GO-Ag dispersion presented a black-green color (Figure 1A). The UV-vis spectrum of pristine GO exhibited characteristic bands, with a maximum absorption band at approximately $230 \mathrm{~nm}$ and a shoulder at $\sim 301 \mathrm{~nm}$, corresponding to $\pi-\pi^{*}$ electronic transitions of $\mathrm{C}=\mathrm{C}$ aromatic bonds and $\mathrm{n}-\pi^{*}$ electronic transitions of $\mathrm{C}=\mathrm{O}$ bonds, respectively (Figure $1 \mathrm{~B}$ ). The attachment of AgNPs to the GO surface was confirmed primarily through the detection of a band at $410 \mathrm{~nm}$, which was attributed to the plasmon resonance of AgNPs. ${ }^{20}$ Moreover, the GO-Ag UVvis spectrum showed that the electronic transitions of $\mathrm{C}=\mathrm{C}$ aromatic bonds red-shifted to approximately $263 \mathrm{~nm}$, and that the shoulder had disappeared. These observations suggest that 


\section{A}
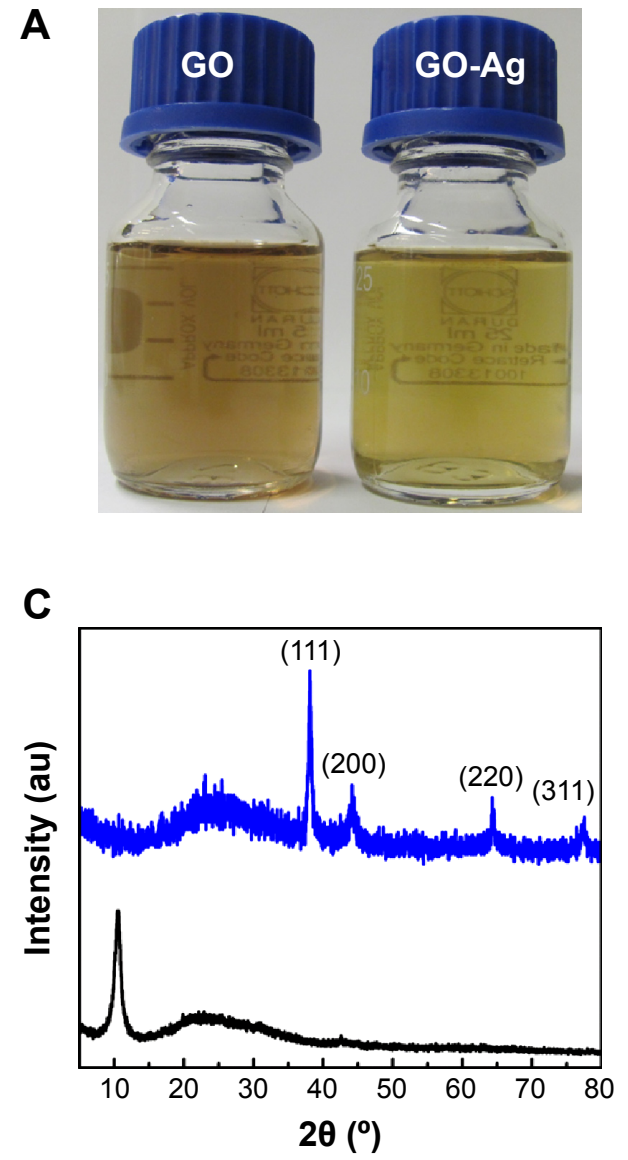

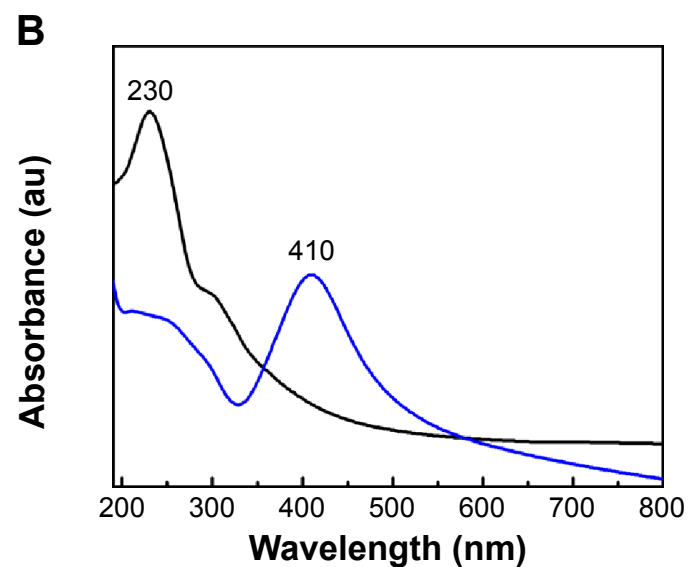

D

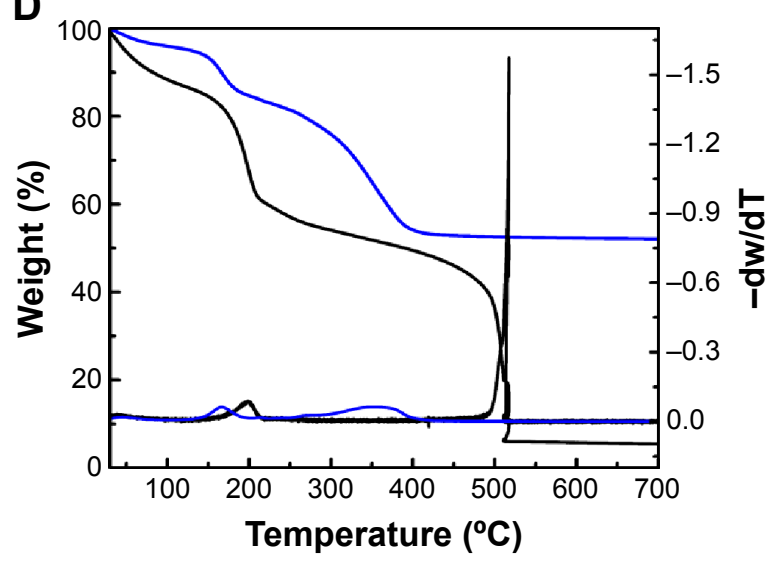

GO GO-Ag

Figure I Photographs of the GO and GO-Ag dispersions (50 $\left.\mu \mathrm{g} \mathrm{mL} \mathrm{L}^{-1}\right)(\mathbf{A})$. UV-vis absorption spectra of GO and GO-Ag dispersions (B). XRD patterns of GO and GO-Ag nanocomposite (C). Thermogravimetric curves of GO and GO-Ag (D).

Abbreviations: GO, graphene oxide; GO-Ag, graphene oxide-silver nanocomposite; XRD, X-ray diffraction; UV-vis, ultraviolet-visible.

GO sheets were simultaneously reduced by $\mathrm{Na}_{3} \mathrm{C}_{6} \mathrm{H}_{5} \mathrm{O}_{7}$ during the formation of the AgNPs, resulting in a partial restoration of $\pi$-conjugation within the graphene sheets. ${ }^{32}$

The attachment of AgNPs to the GO sheet surface was also evaluated by XRD patterns (Figure $1 \mathrm{C}$ ). The GO-Ag diffraction peaks observed at $2 \theta=38.1^{\circ}, 44.3^{\circ}, 64.5^{\circ}$, and $77.5^{\circ}$ matched the crystalline planes of face-centered cubic silver (Joint Committee on Powder Diffraction Standards [JCPDS] card number 07-0783). ${ }^{33}$ Moreover, the peak at $2 \theta=10.5^{\circ}$ that is usually attributed to the stacking of GO sheets disappeared after decoration with the AgNPs. Therefore, the functionalization of the GO surface with the AgNPs might prevent the graphene sheets from restacking. ${ }^{34}$

The TGA of both nanomaterials displayed a two-step decomposition behavior (Figure 1D). The first mass loss in the range of $150^{\circ} \mathrm{C}-210^{\circ} \mathrm{C}$ was attributed to the decomposition of oxygenated functional groups. The second decomposition step was ascribed to the decomposition of the graphitic portion. Interestingly, the $\mathrm{GO}-\mathrm{Ag}$ nanocomposite showed a reduction in thermal decomposition temperatures for the second mass loss step, which occurred approximately $200^{\circ} \mathrm{C}$ earlier in comparison to the GO sample. This phenomenon suggested that AgNPs catalyze the material combustion, leading to a decrease in its decomposition temperature. ${ }^{35}$ Furthermore, as the graphitic domains were completely decomposed at $600^{\circ} \mathrm{C}$, the residues above this temperature on the TGA curve could be related to the silver content on GO-Ag nanocomposite. The final residue was approximately $50 \mathrm{wt} \%$, thus implying that the mass ratio proportion of $\mathrm{Ag}: \mathrm{GO}$ was approximately $1: 1$.

The presence of functional groups on the GO and GO-Ag surfaces was investigated using XPS, and the results are shown in Figure 2. For both nanomaterials, the $\mathrm{C}$ 1s signal was deconvoluted into three peaks (curve fitting was performed using Gaussian and Lorentzian lineshapes), which correspond to $\mathrm{C}-\mathrm{C}\left(\mathrm{C} \mathrm{sp}^{2}\right.$ and $\left.\mathrm{C} \mathrm{sp} \mathrm{sp}^{3}, 285 \mathrm{eV}\right), \mathrm{C}-\mathrm{O}$ (epoxy and hydroxyl, $287 \mathrm{eV}$ ), and $\mathrm{C}=\mathrm{O}$ (carboxyl, $289 \mathrm{eV}$ ). After the decoration of the GO surface with AgNPs, the intensity 

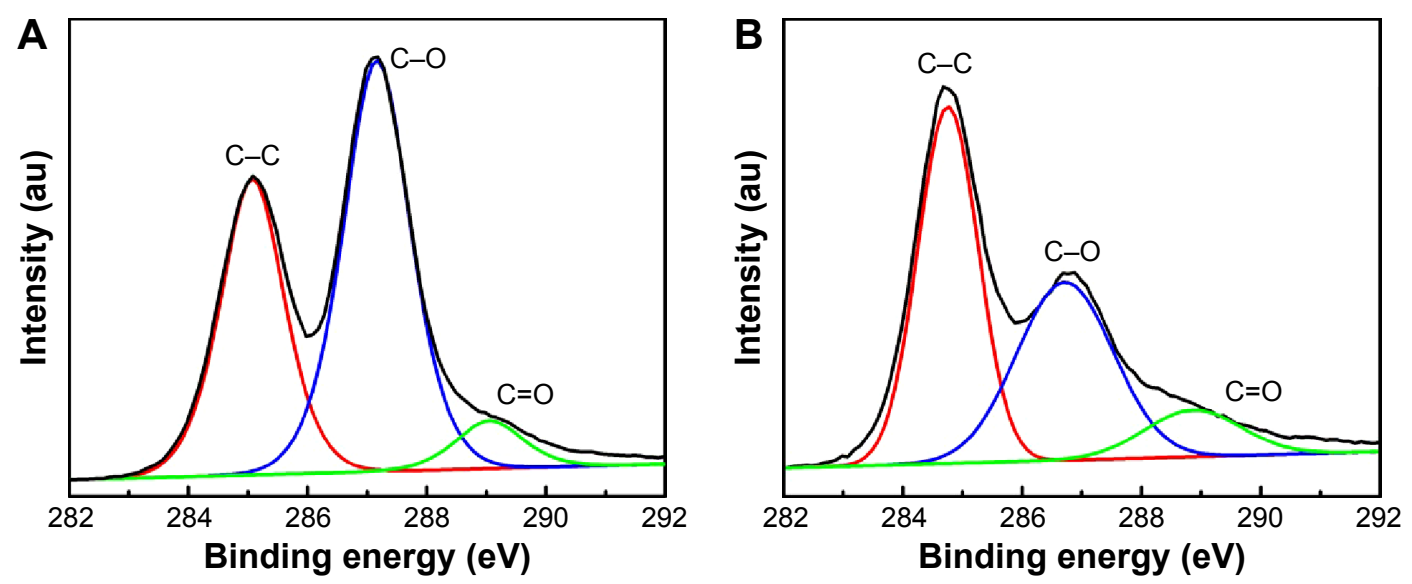

Figure $2 \mathrm{C}$ Is XPS spectra of GO (A) and GO-Ag (B).

Abbreviations: XPS, X-ray photoelectron spectroscopy; GO, graphene oxide; GO-Ag, graphene oxide-silver nanocomposite.

related to the $\mathrm{C}-\mathrm{O}$ signal decreased, whereas the intensity of the $\mathrm{C}-\mathrm{C}$ signal was slightly increased.

It has been reported that $\mathrm{GO}$ undergoes chemical reduction by $\mathrm{Na}_{3} \mathrm{C}_{6} \mathrm{H}_{5} \mathrm{O}_{7}$, restoring $\pi$-conjugation within the graphene sheets. ${ }^{32}$ However, the residual oxygenated groups on the GO-Ag nanocomposite surface were sufficient to maintain the colloidal stability of the nanocomposite in the aqueous dispersion in the current study. The $\mathrm{Ag} 3 \mathrm{~d}$ core-level spectrum (Figure S1) of GO-Ag nanocomposite shows the binding energies of the $\mathrm{Ag} 3 \mathrm{~d}_{3 / 2}$ and $\mathrm{Ag} 3 \mathrm{~d}_{5 / 2}$ electronic states (368.4 and $374.4 \mathrm{eV}$, respectively), which also confirmed the formation of AgNPs on the GO surface. Therefore, the XRD and XPS results indicated the formation of metallic AgNPs on GO sheets. ${ }^{21,22}$ Additional characterization of GO and $\mathrm{GO}-\mathrm{Ag}$ is available in the Figures S2-S4.

The morphological characteristics of both GO and GO-Ag nanocomposite were analyzed by TEM. A typical TEM image of GO exhibited a transparent and stable sheet (Figure 3A). After functionalization with the AgNPs, the TEM image clearly showed highly decorated GO-Ag sheets (Figure 3B). The spherical-like AgNPs were well-dispersed throughout the GO sheets and were exclusively attached to the material surface, demonstrating the strong interaction between the AgNPs and GO (Figure 3C). Figure 3D shows that the average size of AgNPs was $9.4 \pm 2.8 \mathrm{~nm}$. The attachment of AgNPs to the GO surface could be attributed to the interactions between $\mathrm{Ag}^{+}$ions and the oxygen-containing groups on the GO sheets, which provide nucleation sites for anchoring and growth of AgNPs. The deposition of AgNPs may also be related to the adsorption of citrate anions on the GO surface via hydrogen bonding between functional groups of GO and the carboxyl and hydroxyl groups of citrate. Thus, in the current study, the adsorbed citrate anions could have acted as nucleation sites for $\mathrm{Ag}^{+}$ions, leading to a subsequent formation and stabilization of AgNPs on the GO surface. ${ }^{36}$

\section{Antibacterial activity of GO and GO-Ag: MIC, MBC, and time-kill curves}

The antimicrobial properties of GO and GO-Ag nanocomposites were investigated against Gram-negative and Grampositive bacteria. The MIC and MBC values for several bacterial strains are shown in Table 1. The MIC of GO-Ag for MRSA was $15 \mu \mathrm{g} \mathrm{mL}^{-1}$, which was slightly lower than the $30 \mu \mathrm{g} \mathrm{mL}^{-1}$ observed for non-MR S. aureus and E. faecalis. Moreover, the MIC of GO-Ag for MRSA was significantly lower than that presented by the conventional antibiotic oxacillin $\left(31 \mu \mathrm{g} \mathrm{mL}^{-1}\right)$, as seen in Table 2. Among the bacterial strains evaluated, the Gram-negative $A$. baumannii demonstrated the lowest MIC value of $6 \mu \mathrm{g} \mathrm{mL}{ }^{-1}$ in the presence of GO-Ag nanocomposite.

These findings are noteworthy because these bacteria are nosocomial pathogens commonly associated with hospitalacquired infections. ${ }^{3}$ We did not observe a direct correlation between the MIC and MBC values of Gram-positive and Gramnegative bacteria. The MBC/MIC ratio offers information about the nature of the antibacterial activity. For example, when the $\mathrm{MBC} / \mathrm{MIC}$ ratio is between 1 and 2, the sample is considered as a bactericidal agent. On the other hand, if the MBC/MIC ratio is higher than 2, the antimicrobial substance can be classified as a bacteriostatic agent. ${ }^{30}$ In our present study, MBC/MIC ratios indicate that, rather than a bacteriostatic effect, GO-Ag acted as a strong bactericidal agent. Furthermore, no toxicity was found for pristine GO, even at the highest concentration of $60 \mu \mathrm{g} \mathrm{mL}^{-1}$ (Table 1). Additionally, pristine AgNPs exhibited MIC $>80 \mu \mathrm{g} \mathrm{mL}^{-1}$ (Table 2). As a consequence, MIC and MBC values were not determined for pure GO and AgNP samples. Details regarding the synthesis of pristine AgNPs as well as 

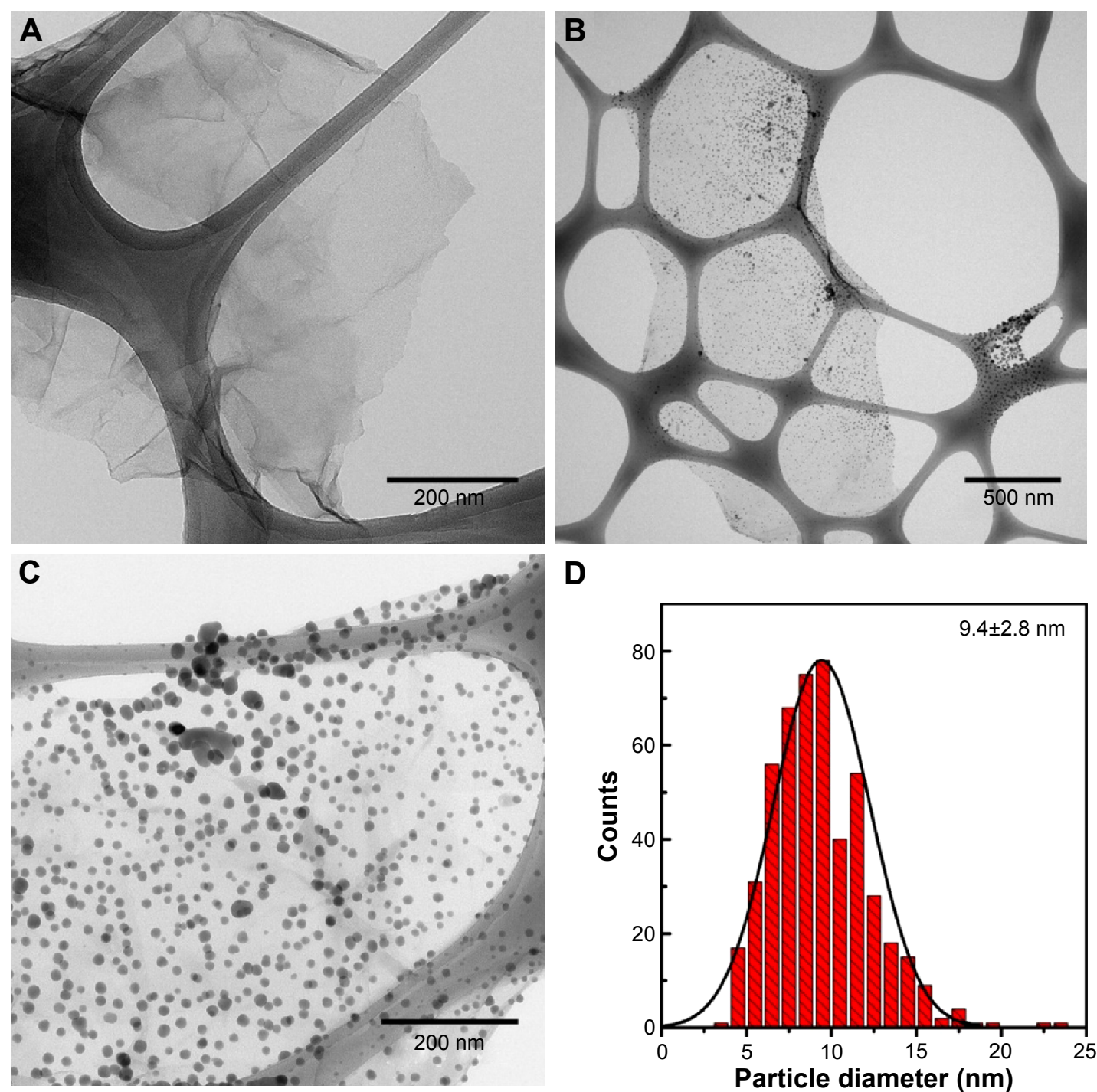

Figure 3 TEM images of GO (A), and GO-Ag sheets (B, C). Size distribution of AgNPs anchored to GO sheets (D). The size distribution was calculated by counting more than 500 nanoparticles in several GO-Ag images, using Imagej software.

Abbreviations: TEM, transmission electron microscopy; GO, graphene oxide; GO-Ag, graphene oxide-silver nanocomposite; AgNPs, silver nanoparticles.

their characterization are described in Supplementary materials, "Synthesis of silver nanoparticles" section (Figures S5-S6).

To investigate the antibacterial kinetics of GO and GO-Ag nanocomposite, we conducted time-kill experiments using
E. coli and MRSA as models for Gram-positive and Gramnegative bacteria, respectively (Figure 4A, B). The time-kill curves for GO exhibited a similar trend compared to the control curve, which suggests that GO was not toxic to the

Table I Values of MIC and MBC for GO and GO-Ag against Gram-positive and Gram-negative bacteria

\begin{tabular}{|c|c|c|c|c|c|}
\hline \multirow[t]{2}{*}{ Strain } & \multicolumn{2}{|c|}{ MIC $\left(\mu \mathrm{g} \mathrm{mL} \mathbf{L}^{-1}\right)$} & \multicolumn{2}{|c|}{ MBC $\left(\mu \mathrm{g} \mathrm{mL}^{-1}\right)$} & \multirow{2}{*}{$\frac{\mathrm{MBC} / \mathrm{MIC}}{\mathrm{GO}-\mathrm{Ag}}$} \\
\hline & GO & $\overline{\text { GO-Ag }}$ & GO & $\overline{\text { GO-Ag }}$ & \\
\hline Staphylococcus aureus N3 I5 (MRSA) & $>60$ & 15 & - & 30 & 2 \\
\hline Staphylococcus aureus ATCC 29213 & $>60$ & 30 & - & 30 & 2 \\
\hline Enterococcus faecalis ATCC 29212 & $>60$ & 30 & - & 60 & 2 \\
\hline Escherichia coli ATCC 25922 & $>60$ & 15 & - & 30 & 2 \\
\hline Acinetobacter baumannii ATCC 19606 & $>60$ & 6 & - & 15 & 2.5 \\
\hline Salmonella enterica Typhimurium LT2 & $>60$ & 30 & - & 60 & 2 \\
\hline Pseudomonas aeruginosa ATCC 27853 & $>60$ & 15 & - & 30 & 2 \\
\hline
\end{tabular}

Abbreviations: MIC, minimal inhibitory concentration; MBC, minimal bactericidal concentration; GO, graphene oxide; GO-Ag, graphene oxide-silver nanocomposite; MRSA, methicillin-resistant Staphylococcus aureus. 
Table 2 Values of MIC and MBC for oxacillin and AgNPs against MRSA and Escherichia coli as model microorganisms

\begin{tabular}{|c|c|c|c|c|}
\hline & \multicolumn{2}{|l|}{ MRSA } & \multicolumn{2}{|l|}{ E. coli } \\
\hline & $\begin{array}{l}\text { MIC } \\
\left(\mu \mathrm{g} \mathrm{mL}^{-1}\right)\end{array}$ & $\begin{array}{l}\text { MBC } \\
\left(\mu \mathrm{g} \mathrm{mL}^{-1}\right)\end{array}$ & $\begin{array}{l}\text { MIC } \\
\left(\mu \mathrm{g} \mathrm{mL}^{-1}\right)\end{array}$ & $\begin{array}{l}\text { MBC } \\
\left(\mu \mathrm{g} \mathrm{mL}^{-1}\right)\end{array}$ \\
\hline Oxacillin & 31 & 62 & 500 & 2,000 \\
\hline AgNPs & $>80$ & - & $>80$ & - \\
\hline
\end{tabular}

Abbreviations: MIC, minimal inhibitory concentration; MBC, minimal bactericidal concentration; AgNPs, silver nanoparticles; MRSA, methicillin-resistant Staphylococcus aureus.

bacterial strains at the concentration of $15 \mu \mathrm{g} \cdot \mathrm{mL}^{-1}$. This observation is consistent with the MIC experiment reported in the "Evaluation of antibacterial activity" section. However, the time-kill curves show an effective antimicrobial effect for the GO-Ag sample at the MIC concentrations $\left(15 \mu \mathrm{g} \mathrm{mL}^{-1}\right.$ for both cultures). A significant decrease in the cellular viability was observed after 2 and 4 hours' contact with E. coli and MRSA cells, respectively. Hence, the time-kill curves demonstrated the ability of GO-Ag to rapidly kill bacterial cells at a very low concentration. These results support the potential application of GO-Ag as an effective antimicrobial agent for the inactivation of relevant clinical pathogens such as MRSA.

\section{Evaluation of morphological integrity of GO-Ag-treated E. coli and MRSA cells}

The morphological changes in E. coli and MRSA cells resulting from exposure to $\mathrm{GO}-\mathrm{Ag}$ nanocomposite were assessed by TEM. Untreated E. coli (Figure 5A, B) and MRSA (Figure 6A, B) exhibited normal rod-shaped and round-shaped morphologies, respectively, both with intact cell membranes. However, when both bacteria were treated with $15 \mu \mathrm{g} \mathrm{mL} \mathrm{m}^{-1}$ of GO-Ag, the cells lost their morphological integrity. E. coli cell walls and membranes were found to be partially disrupted (Figure 5C-E). In addition, a severely damaged $E$. coli cell exhibited leakage of intracellular contents, as shown by the arrows in Figure 5F.

The cell walls and membranes of MRSA were also found to be disrupted (Figure 6C-F). An apparent decrease in cellular volume was also observed (Figure 6D, F; arrows). In general, it was possible to detect the intimate contact between the graphene sheets and the surface of the bacteria. In fact, some bacterial cells seemed to be wrapped by graphene sheets, which likely favored the interaction between the AgNPs on GO-Ag nanocomposite and the bacterial surfaces (Figures $5 \mathrm{C}-\mathrm{F}$ and $6 \mathrm{C}-\mathrm{F}$ ). It is worthy to note that the sample preparation, which involved centrifuging steps, may have also promoted the contact of GO-Ag nanocomposite with the bacterial cells.

\section{Discussion}

In the current study, we report the synthesis of GO functionalized with AgNPs using $\mathrm{Na}_{3} \mathrm{C}_{6} \mathrm{H}_{5} \mathrm{O}_{7}$ as a reducing agent. GO sheets were found to be decorated with spherical AgNPs with an average diameter of $9.4 \mathrm{~nm}$. The bactericidal activity of $\mathrm{GO}$ and GO-Ag was investigated using several nosocomial bacterial strains as model microorganisms. Indeed, our present study was particularly focused on MRSA, because it is a microorganism that is resistant to a variety of antibiotics
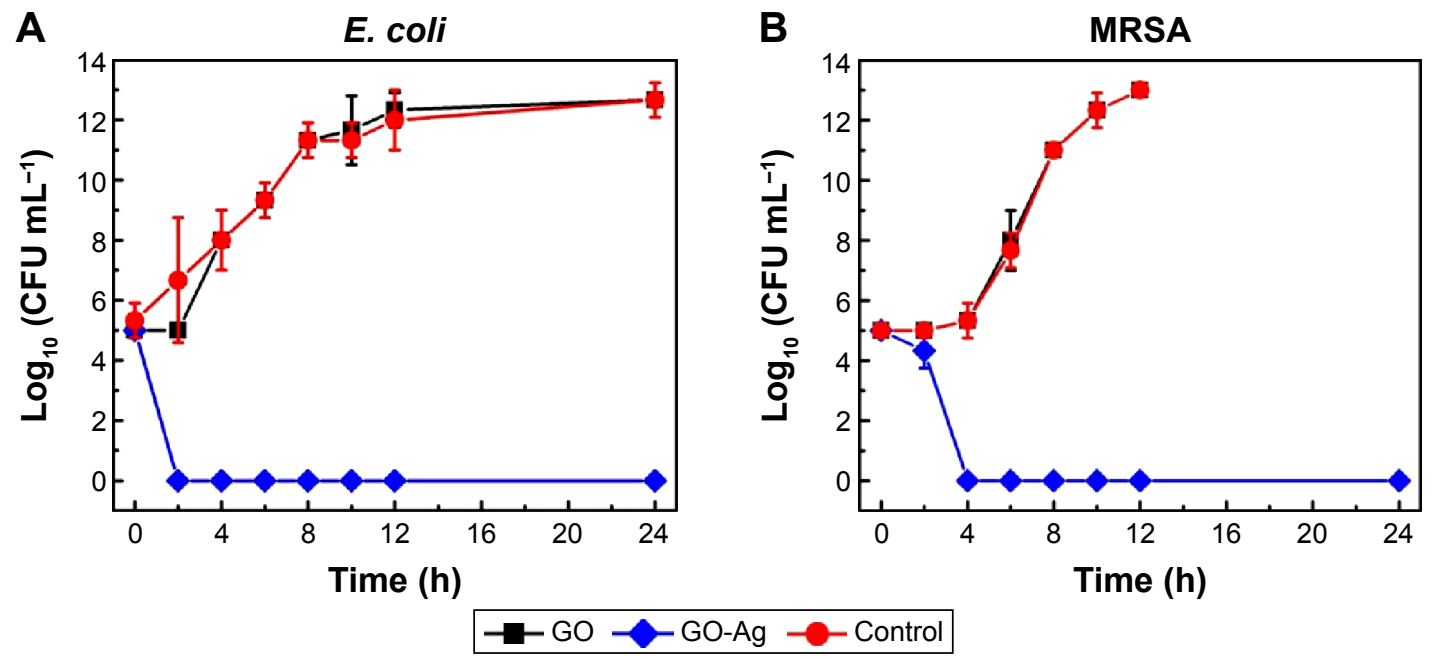

Figure 4 Time-kill curves of Gram-negative Escherichia coli ATCC 25922 (A), and Gram-positive MRSA N3I5 (B).

Note: Error bars represent the standard deviations of three replicates $(n=3)$.

Abbreviations: MRSA, methicillin-resistant Staphylococcus aureus; h, hours; CFU, colony-forming units; GO, graphene oxide; GO-Ag, graphene oxide-silver nanocomposite. 

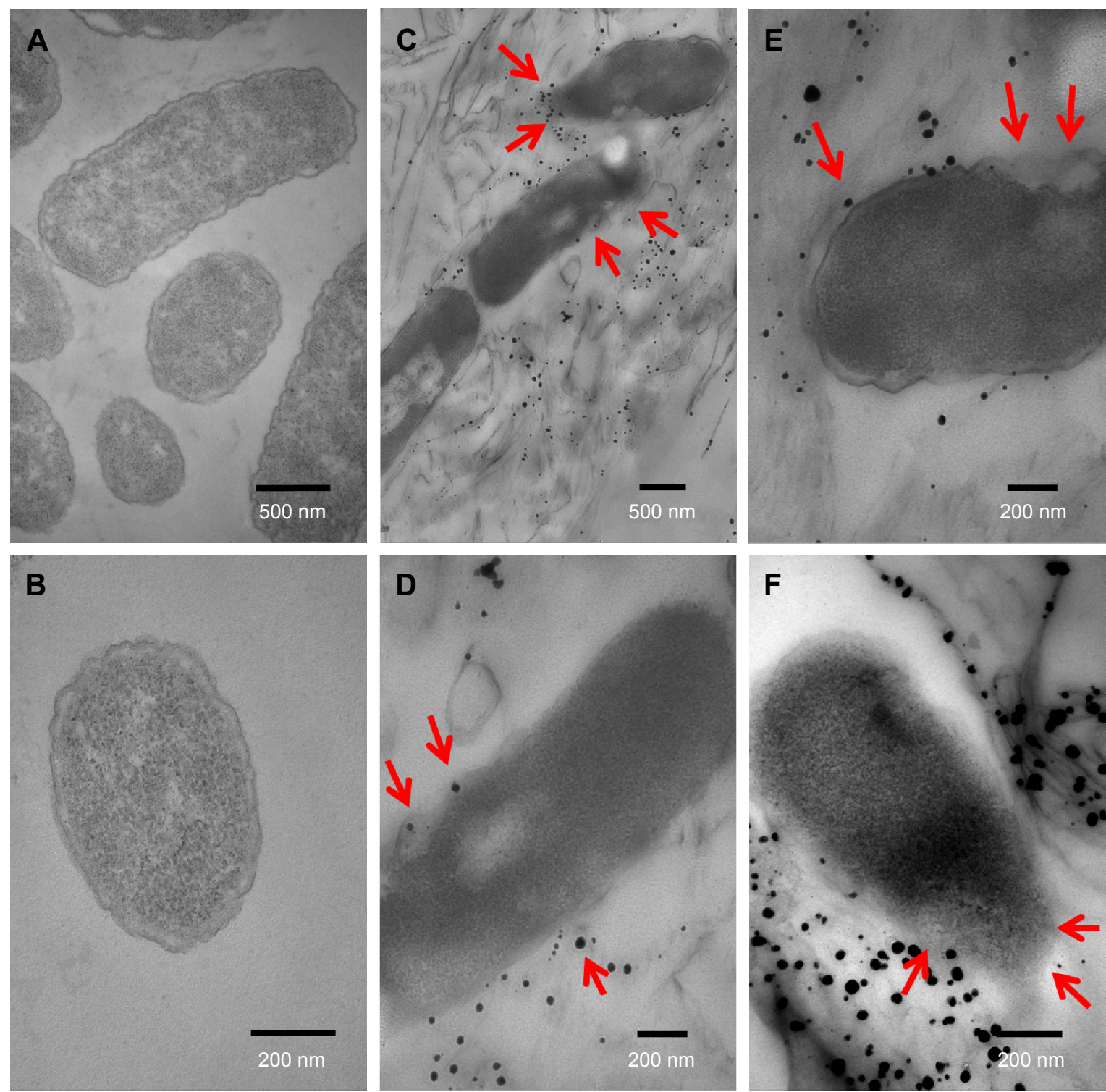

Figure 5 TEM images of Escherichia coli cells not exposed to GO-Ag nanocomposite (A, B); and E. coli cells treated with $15 \mu \mathrm{g} \cdot \mathrm{mL}^{-1} \mathrm{GO}-\mathrm{Ag}$ for $2 \mathrm{~h}(\mathbf{C}-\mathbf{F})$. The cell membranes were found to be disrupted after contact with GO-Ag. The disruption of the bacterial cell and subsequent leaking of intracellular contents are highlighted by red arrows in C-F.

Abbreviations: TEM, transmission electron microscopy; GO-Ag, graphene oxide-silver nanocomposite; $h$, hours.

and is responsible for frequent cases of hospital-acquired infections. ${ }^{37}$

Furthermore, data regarding the antibacterial activity of silver-based graphene nanocomposite toward this multidrugresistant bacterium are scarce. Moreover, antimicrobial nanomaterials are unlikely to cause resistance in pathogen microorganisms, making them promising alternatives for overcoming infectious diseases. ${ }^{10}$ Due to their high surface area and minimal risk to human health, AgNPs have emerged as an effective antimicrobial agent against several microorganisms. ${ }^{9,10,38,39}$ Indeed, graphene-based materials are biocompatible, which contributes to their usefulness as novel antimicrobial platforms. ${ }^{40,41}$
The $15 \mu \mathrm{g} \mathrm{mL}^{-1} \mathrm{MIC}$ of GO-Ag nanocomposite against MRSA cannot be fairly compared to other previous studies, because the toxicity of graphene-silver nanocomposite to this specific bacterial strain has not been reported in the literature yet. Prior studies have already investigated the antibacterial activity of pristine AgNPs toward MRSA. However, higher MIC values have been found for bare AgNPs compared to that observed for our homemade GO-Ag nanocomposite. ${ }^{42-44}$ Ayala-Núñez et $\mathrm{al}^{44}$ reported that commercially obtained AgNPs had an MIC value of $1.8 \mathrm{mg} \mathrm{mL}^{-1}$ against MRSA. Similarly, AgNPs with different size distributions (from $9 \mathrm{~nm}$ to $30 \mathrm{~nm}$ ) displayed MIC values from $14.4 \mu \mathrm{g} \mathrm{mL}^{-1}$ to $260 \mu \mathrm{g} \mathrm{mL}^{-1}$ against MRSA. ${ }^{42}$ 

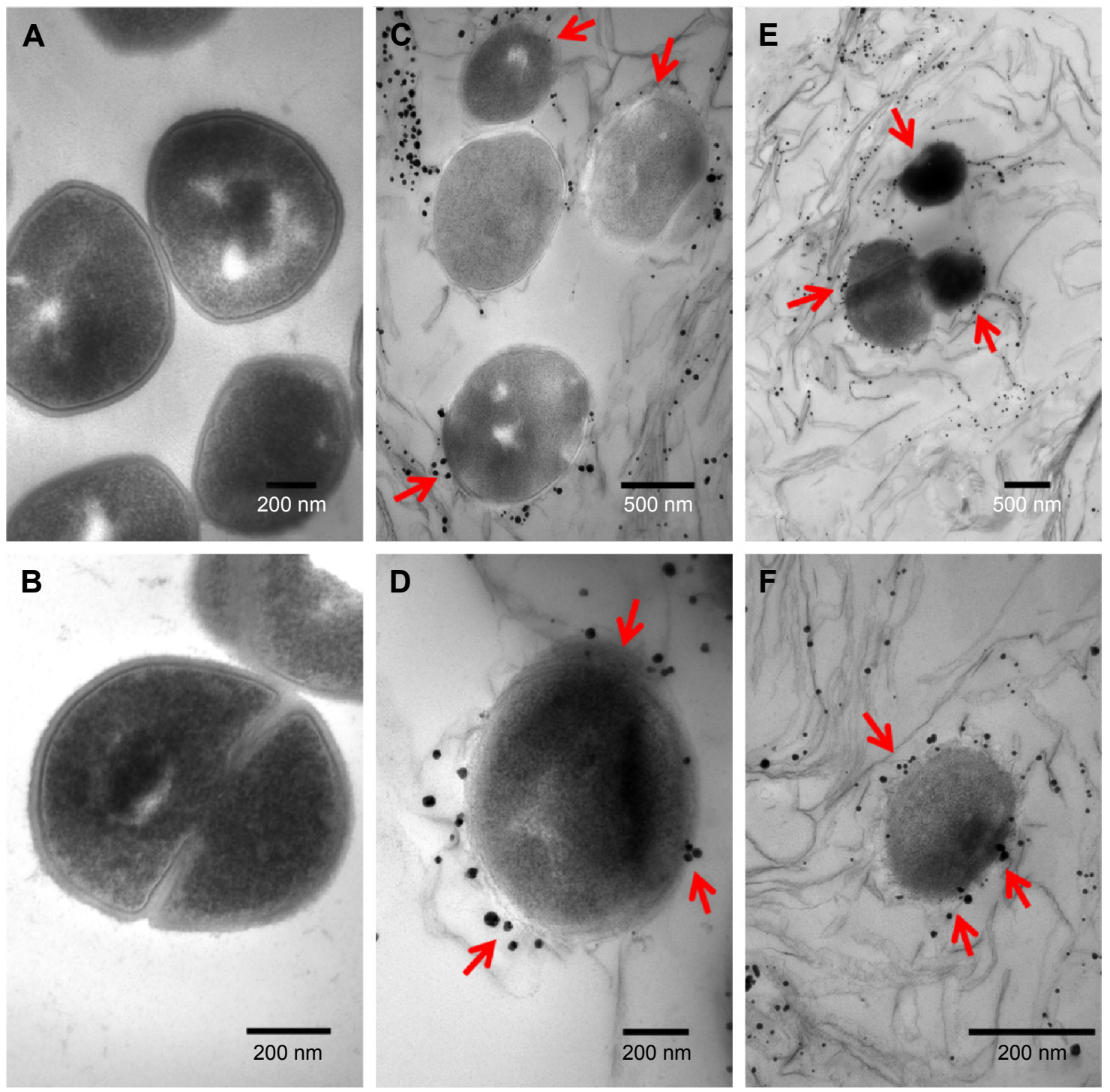

Figure 6 TEM images of MRSA cells not exposed to GO-Ag nanocomposite (A, B); and MRSA cells treated with $15 \mu \mathrm{g} \cdot \mathrm{mL}^{-1} \mathrm{GO}-\mathrm{Ag}$ for $2 \mathrm{~h}$ (C-F). The cell membranes were severely damaged after exposure to GO-Ag. Visible damage on the cell surface is indicated by red arrows (C-F).

Abbreviations: MRSA, methicillin-resistant Staphylococcus aureus; TEM, transmission electron microscopy; GO-Ag, graphene oxide-silver nanocomposite; h, hours.

When compared to other previous studies, the present GO-Ag sample revealed an enhanced antibacterial activity. For instance, Liu et $\mathrm{a}^{45}$ showed that $E$. coli cells were inactivated at a GO-Ag composite concentration of $80 \mu \mathrm{g} \mathrm{mL}$. Shen et $\mathrm{al}^{24}$ demonstrated that Ag-chemically converted graphene nanocomposite destroyed Colibacillus spp., S. aureus, and Candida albicans cells at a concentration of $50 \mu \mathrm{g} \mathrm{mL}^{-1}$. In addition, our GO-Ag nanocomposite showed almost identical toxic effects against either MRSA or non-MR S. aureus, which suggests the antibacterial activity of GO-Ag was not affected by the drug-resistance mechanisms of MRSA. In other words, the GO-Ag nanocomposite seemed to not suppress the expression of specific drug-resistance proteins, because both MRSA and non-MR strains were similarly inhibited by the nanocomposite. ${ }^{44}$ Furthermore, GO-Ag was able to inactivate E. faecalis and A. baumannii (Table 1), two bacteria also frequently associated with nosocomial infections. ${ }^{46,47}$

Pristine AgNPs stabilized with citrate did not display inhibitory activity against either MRSA or E. coli at a concentration of $80 \mu \mathrm{g} \mathrm{mL}^{-1}$ (Table 2). This result is in accordance with various studies that have observed a loss of antibacterial activity for citrate-capped AgNPs. ${ }^{48-50}$ For instance, Taner et a ${ }^{50}$ described that bare citrate-AgNPs were not toxic to $E$. coli cells at a concentration of $150 \mu \mathrm{g} \mathrm{mL}^{-1}$, whereas silver-copper nanoalloys exhibited an MIC of $0.5 \mu \mathrm{g} \mathrm{mL}{ }^{-1}$. Additionally, many authors have reported that graphene-silver nanocomposite presented an improved antibacterial activity compared to bare AgNPs..$^{21,23,51-53} \mathrm{Tian}$ et al ${ }^{53}$ 
for example, showed that $85.3 \%$ and $28 \%$ of viable $S$. aureus cells were inhibited by GO functionalized with iron oxide nanoparticles and AgNPs, and bare AgNPs, respectively. Ma et $\mathrm{al}^{21}$ also observed the growth of colonies after contact between E.coli and pristine AgNPs, while no colonies were visualized when the same bacteria was treated with silvermodified GO. Finally, Xu et $\mathrm{al}^{23}$ reported that reduced GO decorated with AgNPs nanocomposite performed fourfold better than bare AgNPs, showing complete inhibition of E. coli cells at a concentration of $12.5 \mu \mathrm{g} \mathrm{mL} \mathrm{m}^{-1}$.

Except for the fact that $E$. coli cells underwent a more rapid inactivation mechanism, MRSA and E. coli presented very similar antibacterial kinetics in the presence of GO-Ag sheets. In fact, $E$. coli cells were found to be completely inactivated by GO-Ag approximately 2 hours earlier than MRSA cells. This observation may be related to the differences in the cellular wall structure between Gram-negative and Gram-positive bacteria. Gram-positive MRSA has a thicker peptidoglycan layer that may provide improved physical protection against the biocidal effects of GO-Ag nanocomposite. ${ }^{33}$

Although some studies have attributed antimicrobial activity to pristine GO sheets, ${ }^{40,41,54,55}$ our GO sample did not display toxicity to the bacterial strains at the range of concentrations investigated. These contradictory results might be related to the distinctive physicochemical properties of each graphene-based sample, such as surface area, oxidation degree, thickness and lateral dimensions of sheets, carbon precursor source, and purity. ${ }^{56}$ Therefore, further investigation is needed to elucidate the correlation between the most relevant physicochemical properties of GO sheets and their possible antibacterial activity. Our result is consistent with other previous studies that have reported no toxicity for GO nanosheets against bacterial cells. ${ }^{19,57}$

Despite the abundant studies ${ }^{19-25}$ regarding the antibacterial activity of GO-Ag nanocomposite, the mechanism of toxicity of this nanomaterial is not completely understood. However, AgNPs may be considered the major contributor to the antibacterial effect of GO-Ag, and their inhibitory effect can be a combination of several mechanisms. Mostly, AgNPs are able to release $\mathrm{Ag}^{+}$ions, which possess great affinity for the thiol groups of enzymes and proteins. These interactions between silver ions and the sulfur-containing functional groups of proteins can lead to losses in membrane permeability, inhibition of the respiratory chain, and deactivation of essential cellular components such as DNA. ${ }^{58,59}$ The antibacterial activity may also be caused by the direct contact between GO-Ag sheets and the bacterial cell surface. As a consequence, the extraction of phospholipids and severe damage to the membrane and cellular walls may be possible. ${ }^{60}$ In addition, GO-Ag nanocomposite is likely able to deploy its toxicity through oxidative stress mechanisms. Therefore, microbial cells can be inactivated by reactive oxygen species generated by AgNPs under aerobic conditions. ${ }^{61-64}$ Some studies have hypothesized that the enhanced antibacterial ${ }^{45}$ activity of the graphene-silver nanocomposite might be a result of a synergistic effect between GO sheets and AgNPs. ${ }^{23}$ Then, GO sheets would provide a large surface area for bacterial attachment, thus allowing a more intimate contact between the AgNPs and the surface of bacterial cells. ${ }^{19,25,51-53}$

In our current study, the most likely antimicrobial mechanism for the GO-Ag nanocomposite might be related to the release of $\mathrm{Ag}^{+}$ions and the direct contact of bacterial cells with the AgNPs attached to the GO surface. As observed by TEM analysis, GO-Ag sheets are accumulated around the bacterial cell surfaces (Figures $5 \mathrm{C}-\mathrm{F}$ and $6 \mathrm{C}-\mathrm{F}$ ). Despite the fact that both $\mathrm{GO}-\mathrm{Ag}$ and bacteria have negatively charged surfaces, hydrogen bonding between the oxygenated groups present on GO-Ag sheets and the proteins of the cell membranes facilitates the direct contact of GO-Ag sheets with the bacterial cells. The wrapping of GO-Ag sheets around the microbial cells could eventually block the cells' access to nutrients and could induce cell death. ${ }^{21}$ Indeed, MRSA and $E$. coli cell walls and membranes became disordered and fragmented (Figures $5 \mathrm{C}-\mathrm{F}$ and $6 \mathrm{C}-\mathrm{F}$ ). The formation of pits and holes in the membrane upon contact with $\mathrm{GO}-\mathrm{Ag}$ nanocomposite might increase cell permeability, thus allowing the leakage of cytoplasmic fluids and further cellular inactivation..$^{59,64,65}$

To the best of our knowledge, our present study adds some novelty to this field, because this is the first report concerning the use of a graphene-based nanocomposite against the drug-resistant bacteria MRSA. We believe that further efforts are still needed to better clarify the antibacterial mechanisms of GO-Ag at the molecular level. Nevertheless, our findings represent a step forward in the understanding of how graphene-based nanocomposites interact with microorganisms. Furthermore, the results presented herein may support the use of GO-Ag as an effective antimicrobial agent to prevent bacterial contamination in clinical facilities.

\section{Conclusion}

In summary, we reported a straightforward and feasible method to synthesize GO-Ag nanocomposite using $\mathrm{Na}_{3} \mathrm{C}_{6} \mathrm{H}_{5} \mathrm{O}_{7}$ as a reducing agent. The results showed that $\mathrm{GO}$ sheets were decorated with spherical AgNPs with an average diameter of $9.4 \mathrm{~nm}$. The AgNPs were highly dispersed 
throughout the GO sheets and were exclusively supported on the material surface. The GO-Ag nanocomposite presented broad-spectrum antibacterial activity against bacteria commonly found in hospital environments, such as $E$. coli, E. faecalis, A. baumannii, and the antibiotic-resistant MRSA. However, no toxicity was observed for pristine GO (up to $60 \mu \mathrm{g} \mathrm{mL}^{-1}$ ) or for bare citrate-AgNPs (up to $80 \mu \mathrm{g} \mathrm{mL}^{-1}$ ). Regarding the antibacterial kinetics, $100 \%$ of MRSA cells were inactivated after 4 hours' contact with GO-Ag, while $E$. coli cells were completely inactivated approximately 2 hours earlier. TEM images revealed morphological changes to $E$. coli and MRSA cells resulting from direct contact with GO-Ag nanocomposite. The images showed that GO-Ag sheets accumulated around the bacterial cell surfaces, thus leading to cell inactivation. These results support substantial evidence for how GO-Ag nanocomposite interacts with MRSA and E. coli cells, indicating that GO-Ag is a promising antibacterial agent for biomedical applications.

\section{Acknowledgments}

The authors are thankful to the São Paulo State Research Foundation (FAPESP; São Paulo, Brazil); the National Council for Technological and Scientific Development (CNPq; Brasília, Brazil); the National Institute of Science, Technology and Innovation in Complex Functional Materials (INOMAT/INCT; Campinas, Brazil); the Brazilian Nanotoxicology Network (CigeNanotox); and the Laboratory of Synthesis of Nanostructures and Interaction with Biosystems (NanoBioss; Campinas, Brazil) for their financial support. The authors are also grateful to the Brazilian Nanotechnology National Laboratory for Research in Energy and Materials for technical support on XPS analysis.

Author Andreia Fonseca de Faria is currently affiliated with the Department of Chemical and Environmental Engineering, Yale University, New Haven, CT, USA.

\section{Disclosure}

The authors report no conflicts of interest in this work.

\section{References}

1. Maple PAC, Hamilton-Miller JM, Brumfitt W. World-wide antibiotic resistance in methicillin-resistant Staphylococcus aureus. Lancet. 1989; $1: 537-540$.

2. Hiramatsu K, Cui L, Kuroda M, Ito T. The emergence and evolution of methicillin-resistant Staphylococcus aureus. Trends Microbiol. 2001; 9:486-493.

3. Bereket W, Hemalatha K, Getenet B, et al. Update on bacterial nosocomial infections. Eur Rev Med Pharmacol Sci. 2012;16:1039-1044.

4. Ayliffe GAJ. Recommendations for the Control of Methicillin-Resistant Staphylococcus aureus (MRSA). Geneva, Switzerland: World Health Organization. 2012. Available from: http://apps.who.int/medicinedocs/ documents/s16211e/s16211e.pdf. Accessed February 2, 2015.
5. Emerging Infections Program Network. Active Bacterial Core Surveillance Report. Methicillin-resistant Staphylococcus aureus. Atlandta, GA: Centers for Disease Control and Prevention; 2012. Available from: http://www.cdc.gov/abcs/reports-findings/survreports/mrsa12.pdf. Accessed February 2, 2015.

6. Alvarez C, Labarca J, Salles M. Prevention strategies for methicillinresistant Staphylococcus aureus (MRSA) in Latin America. Braz J Infect Dis. 2010;14:S107-S118.

7. Michel M, Gutmann L. Methicillin-resistant Staphylococcus aureus and vancomycin-resistant enterococci: therapeutic realities and possibilities. Lancet. 1997;349:1901-1906.

8. Arias CA, Murray BE. Antibiotic-resistant bugs in the 21 st century - a clinical super-challenge. $N$ Engl J Med. 2009;360:439-443.

9. Taylor E, Webster TJ. Reducing infections through nanotechnology and nanoparticles. Int J Nanomedicine. 2011;6:1463-1473.

10. Huh AJ, Kwon YJ. "Nanoantibiotics": a new paradigm for treating infectious diseases using nanomaterials in the antibiotics resistant era. J Control Release. 2011;156:128-145.

11. Dreyer DR, Todd AD, Bielawski CW. Harnessing the chemistry of graphene oxide. Chem Soc Rev. 2014;43:5288-5301.

12. Kanakia S, Toussaint JD, Chowdhury SM, et al. Physicochemical characterization of a novel graphene-based magnetic resonance imaging contrast agent. Int J Nanomedicine. 2013;8:2821-2833.

13. Lalwani G, Henslee AM, Farshid B, et al. Two-dimensional nanostructure-reinforced biodegradable polymeric nanocomposites for bone tissue engineering. Biomacromolecules. 2013;14:900-909.

14. Liu JQ, Cui L, Losic D. Graphene and graphene oxide as new nanocarriers for drug delivery applications. Acta Biomater. 2013;9:9243-9257.

15. Durán N, Martinez DS, Silveira CP, et al. Graphene oxide: a carrier for pharmaceuticals and a scaffold for cell interactions. Curr Top Med Chem. 2015;15:309-327.

16. Talukdar Y, Rashkow JT, Lalwani G, Kanakia S, Sitharaman B. The effects of graphene nanostructures on mesenchymal stem cells. Biomaterials. 2014;35:4863-4877.

17. Mullikc Chowdhury S, Lalwani G, Zhang K, Yang JY, Neville K, Sitharaman B. Cell specific cytotoxicity and uptake of graphene nanoribbons. Biomaterials. 2013;34:283-293.

18. de Faria AF, Perreault F, Shaulsky E, Arias Chavez LH, Elimelech M. Antimicrobial electrospun biopolymer nanofiber mats functionalized with graphene oxide-silver nanocomposites. ACS Appl Mater Interfaces. 2015;7:12751-12759.

19. de Faria AF, Martinez DST, Meira SM, et al. Anti-adhesion and antibacterial activity of silver nanoparticles supported on graphene oxide sheets. Colloids Surf B Biointerfaces. 2014;113:115-124.

20. Das MR, Sarma RK, Saikia R, Kale VS, Shelke MV, Sengupta P. Synthesis of silver nanoparticles in an aqueous suspension of graphene oxide sheets and its antimicrobial activity. Colloids Surf B Biointerfaces. 2011;83:16-22.

21. Ma JZ, Zhang JT, Xiong ZG, Yong Y, Zhao XS. Preparation, characterization and antibacterial properties of silver-modified graphene oxide. J Mater Chem. 2011;21:3350-3352.

22. Zhou Y, Yang J, He T, Shi H, Cheng X, Lu Y. Highly stable and dispersive silver nanoparticle-graphene composites by a simple and low-energy-consuming approach and their antimicrobial activity. Small. 2013;9:3445-3454.

23. Xu WP, Zhang LC, Li JP, et al. Facile synthesis of silver-graphene oxide nanocomposites and their enhanced antibacterial properties. J Mater Chem. 2011;21:4593-4597.

24. Shen JF, Shi M, Li N, et al. Facile synthesis and application of Ag-chemically converted graphene nanocomposite. Nano Res. 2010;3:339-349.

25. Tang J, Chen Q, Xu LG, et al. Graphene oxide-silver nanocomposite as a highly effective antibacterial agent with species-specific mechanisms. ACS Appl Mater Interfaces. 2013;5:3867-3874.

26. Marambio-Jones C, Hoek EM. A review of the antibacterial effects of silver nanomaterials and potential implications for human health and the environment. J Nanopart Res. 2010;12:1531-1551.

27. Lok CN, Ho CM, Chen R, et al. Silver nanoparticles: partial oxidation and antibacterial activities. J Biol Inorg Chem. 2007;12:527-534. 
28. Tung VC, Allen MJ, Yang Y, Kaner RB. High-throughput solution processing of large-scale graphene. Nat Nanotechnol. 2009;4:25-29.

29. Turkevich J, Stevenson PC, Hillier J. A study of the nucleation and growth processes in the synthesis of colloidal gold. Discuss Faraday Soc. 1951;11:55-75.

30. Clinical and Laboratory Standards Institute. Methods for Dilution Antimicrobial Susceptibility Tests for Bacteria that Grow Aerobically. Vol 35. 8th ed. Wayne, PA: Clinical and Laboratory Standards Institute; 2015

31. Kuroda M, Ohta T, Uchiyama I, et al. Whole genome sequencing of meticillin-resistant Staphylococcus aureus. Lancet. 2001;357:1225-1240

32. Wan WB, Zhao Z, Hu H, Gogotsi Y, Qiu J. Highly controllable and green reduction of graphene oxide to flexible graphene film with high strength. Mater Res Bull. 2013;48:4797-4803.

33. de Faria AF, de Moraes ACM, Marcato PD, et al. Eco-friendly decoration of graphene oxide with biogenic silver nanoparticles: antibacterial and antibiofilm activity. J Nanopart Res. 2014;16:1-16.

34. Li J, Liu CY. Ag/graphene heterostructures: synthesis, characterization and optical properties. Eur J Inorg Chem. 2010;8:1244-1248.

35. Faria AF, Martinez DST, Moraes AC, et al. Unveiling the role of oxidation debris on the surface chemistry of graphene through the anchoring of Ag nanoparticles. Chem Mater. 2012;24:4080-4087.

36. Zhang Z, Chen $\mathrm{H}$, Xing $\mathrm{C}$, et al. Sodium citrate: A universal reducing agent for reduction/decoration of graphene oxide with au nanoparticles. Nano Res. 2011;4:599-611.

37. Enright MC, Robinson DA, Randle G, Feil EJ, Grundmann H, Spratt BG. The evolutionary history of methicillin-resistant Staphylococcus aureus (MRSA). Proc Natl Acad Sci U S A. 2002;99:7687-7692.

38. Seil JT, Webster TJ. Antimicrobial applications of nanotechnology: methods and literature. Int J Nanomedicine. 2012;7:2767-2781.

39. Seo Y, Hwang J, Kim J, Jeong Y, Hwang MP, Choi J. Antibacterial activity and cytotoxicity of multi-walled carbon nanotubes decorated with silver nanoparticles. Int J Nanomedicine. 2014;9:4621-4629.

40. Akhavan O, Ghaderi E. Toxicity of graphene and graphene oxide nanowalls against bacteria. ACS Nano. 2010;4:5731-5736.

41. Hu WB, Peng C, Luo WJ, et al. Graphene-based antibacterial paper. ACS Nano. 2010;4:4317-4323.

42. Guzman M, Dille J, Godet S. Synthesis and antibacterial activity of silver nanoparticles against gram-positive and gram-negative bacteria Nanomedicine. 2012;8:37-45.

43. Martinez-Gutierrez F, Olive PL, Banuelos A, et al. Synthesis, characterization, and evaluation of antimicrobial and cytotoxic effect of silver and titanium nanoparticles. Nanomedicine. 2010;6:681-688.

44. Ayala-Núñez NV, Villegas HHL, Turrent LDCI, Padilla CR. Silver nanoparticles toxicity and bactericidal effect against methicillin-resistant Staphylococcus aureus: nanoscale does matter. Nanobiotechnology. 2009;5:2-9.

45. Liu L, Liu JC, Wang Y, Yan X, Sun DD. Facile synthesis of monodispersed silver nanoparticles on graphene oxide sheets with enhanced antibacterial activity. New J Chem. 2011;35:1418-1423.

46. Durante-Mangoni E, Utili R, Zarrilli R. Combination therapy in severe Acinetobacter baumannii infections: an update on the evidence to date. Future Microbiol. 2014;9:773-789.

47. Werner G, Coque TM, Franz CM, et al. Antibiotic resistant enterococci - tales of a drug resistance gene trafficker. Int J Med Microbiol. 2013;303:360-379.
48. Amany A, El-Rab SFG. Effect of reducing and protecting agents on size of silver nanoparticles and their anti-bacterial activity. Der Pharma Chemica. 2012;4:53-65.

49. Borah D, Deka P, Bhattacharjee P, Changmai A, Yadav RNS. Ocimum sanctum mediated silver nano particles showed better antimicrobial activities compared to citrate stabilized silver nano particles against multidrug resistant bacteria. J Pharm Res. 2013;7:478-482.

50. Taner M, Sayar N, Yulug IG, Suzer S. Synthesis, characterization and antibacterial investigation of silver-copper nanoalloys. J Mater Chem. 2011;21:13150-13154.

51. Barua S, Thakur S, Aidew L, Buragohain AK, Chattopadhyay P, Karak N. One step preparation of a biocompatible, antimicrobial reduced graphene oxide-silver nanohybrid as a topical antimicrobial agent. RSC Adv. 2014;4:9777-9783.

52. Han YJ, Luo ZM, Yuwen L, Tian J, Zhu X, Wang L. Synthesis of silver nanoparticles on reduced graphene oxide under microwave irradiation with starch as an ideal reductant and stabilizer. Appl Surf Sci. 2013;266:188-193.

53. Tian TF, Shi XZ, Cheng L, et al. Graphene-based nanocomposite as an effective, multifunctional, and recyclable antibacterial agent. $A C S$ Appl Mater Inter. 2014;6:8542-8548.

54. Liu SB, Zeng TH, Hofmann M, et al. Antibacterial activity of graphite, graphite oxide, graphene oxide, and reduced graphene oxide: membrane and oxidative stress. ACS Nano. 2011;5:6971-6980.

55. Gurunathan S, Han JW, Dayem AA, Eppakayala V, Kim JH. Oxidative stress-mediated antibacterial activity of graphene oxide and reduced graphene oxide in Pseudomonas aeruginosa. Int J Nanomedicine. 2012; 7:5901-5914

56. Sanchez VC, Jachak A, Hurt RH, Kane AB. Biological interactions of graphene-family nanomaterials: an interdisciplinary review. Chem Res Toxicol. 2012;25:15-34.

57. Ruiz ON, Fernando KA, Wang B, et al. Graphene oxide: a nonspecific enhancer of cellular growth. ACS Nano. 2011;5:8100-8107.

58. Rai M, Yadav A, Gade A. Silver nanoparticles as a new generation of antimicrobials. Biotechnol Adv. 2009;27:76-83.

59. Morones JR, Elechiguerra JL, Camacho A, et al. The bactericidal effect of silver nanoparticles. Nanotechnology. 2005;16:2346-2353.

60. Tu YS, Lv M, Xiu P, et al. Destructive extraction of phospholipids from Escherichia coli membranes by graphene nanosheets. Nat Nanotechnol. 2013;8:594-601.

61. Durán N, Marcato PD, Conti RD, Alves OL, Costa F, Brocchi M. Potential use of silver nanoparticles on pathogenic bacteria, their toxicity and possible mechanisms of action. J Braz Chem Soc. 2010;21:949-959.

62. Pal S, Tak YK, Song JM. Does the antibacterial activity of silver nanoparticles depend on the shape of the nanoparticle? A study of the gram-negative bacterium Escherichia coli. Appl Environ Microbiol. 2007;73:1712-1720.

63. Holtz RD, Lima BA, Souza AG, Brocchi M, Alves OL. Nanostructured silver vanadate as a promising antibacterial additive to water-based paints. Nanomedicine. 2012;8:935-940.

64. Sondi I, Salopek-Sondi B. Silver nanoparticles as antimicrobial agent: a case study on E. coli as a model for Gram-negative bacteria. J Colloid Interface Sci. 2004;275:177-182.

65. Raffi M, Hussain F, Bhatti TM, Akhter JI, Hameed A, Hasan MM. Antibacterial characterization of silver nanoparticles against $E$. coli ATCC-15224. J Mater Sci Technol. 2008;24:192-196. 


\section{Supplementary materials}

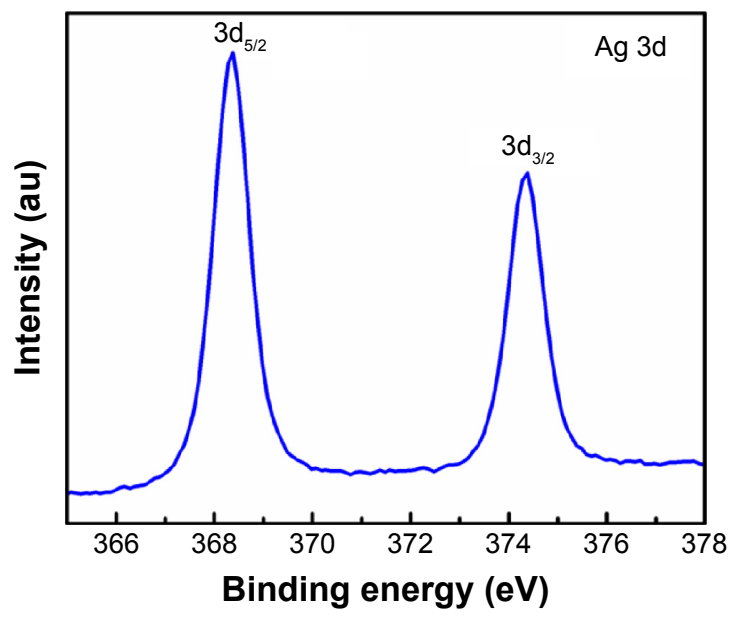

Figure SI Ag 3d XPS spectrum of GO-Ag nanocomposite.

Abbreviations: XPS, X-ray photoelectron spectroscopy; GO, graphene oxide.

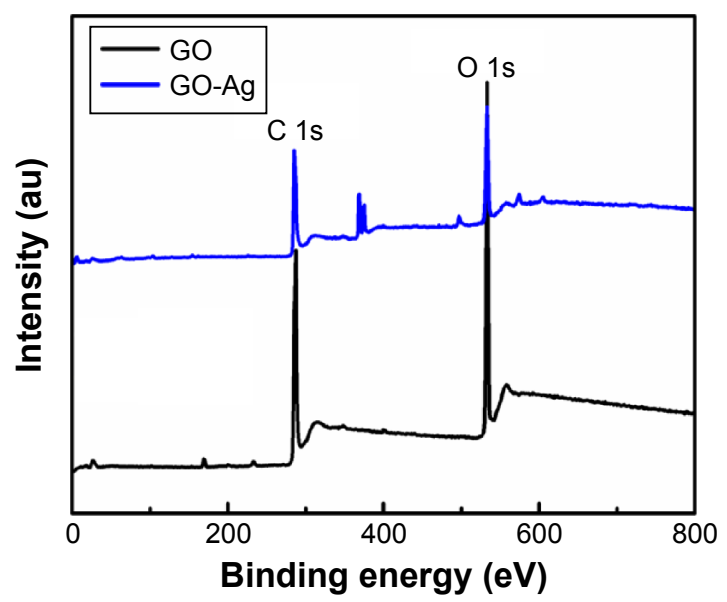

Figure S2 XPS survey spectra of GO and GO-Ag nanocomposite. Note: (C Is-carbon and $O$ Is-oxygen).

Abbreviations: XPS, X-ray photoelectron spectroscopy; GO, graphene oxide.

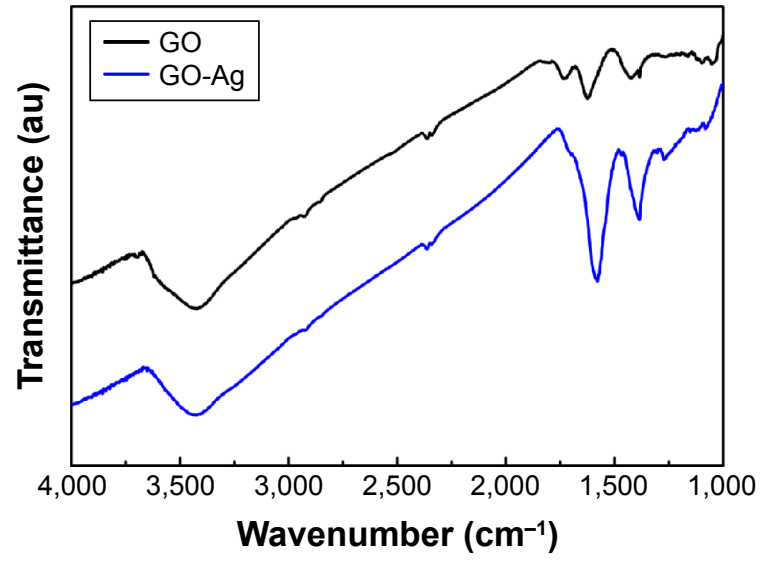

Figure S3 FTIR spectra of GO and GO-Ag nanocomposites. Abbreviations: FTIR, Fourier transform infrared; GO, graphene oxide.

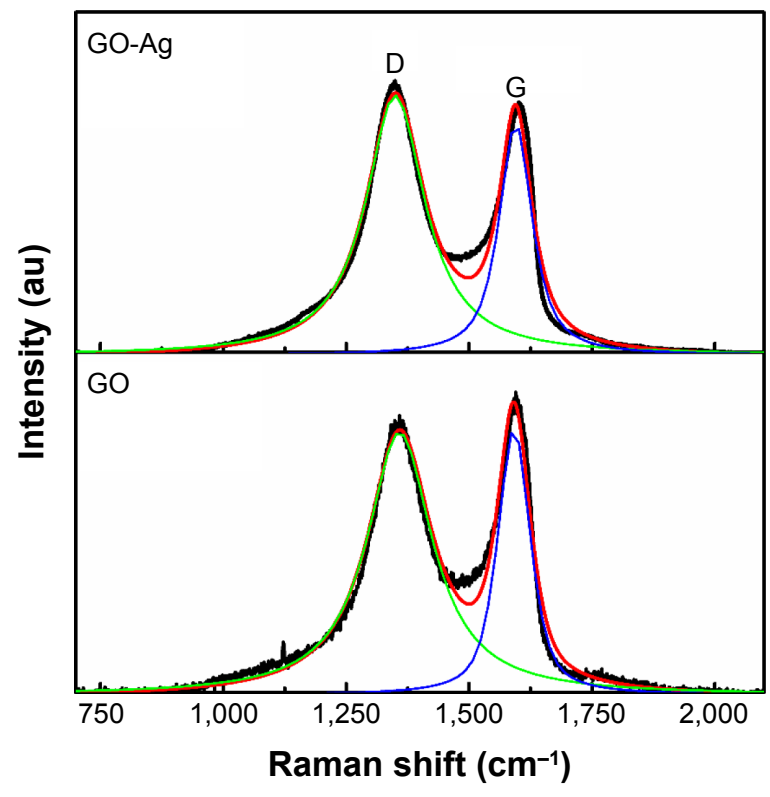

Figure S4 Raman spectra of GO and GO-Ag nanocomposites. Abbreviation: GO, graphene oxide.

\section{Synthesis of silver nanoparticles}

The silver nanoparticles (AgNPs) were produced by the Turkevich method using sodium citrate as the reducing/ stabilizing agent. For this procedure, $8.4 \mathrm{mg}$ of $\mathrm{AgNO}_{3}$ was dissolved in $40 \mathrm{~mL}$ of deionized water. This solution was transferred to a two-neck round-bottom flask and heated at reflux. As soon as it began to boil, $10 \mathrm{~mL}$ of a $1.0 \times 10^{-3} \mathrm{~mol} \mathrm{~L}^{-1}$ sodium citrate solution was added dropwise. The reaction was maintained at $130^{\circ} \mathrm{C}$ for 30 minutes. The color of the solution slowly turned yellow-green, indicating the formation of the AgNPs. The AgNPs were dialyzed for a few hours to remove residual salts (Fisherbrand dialysis

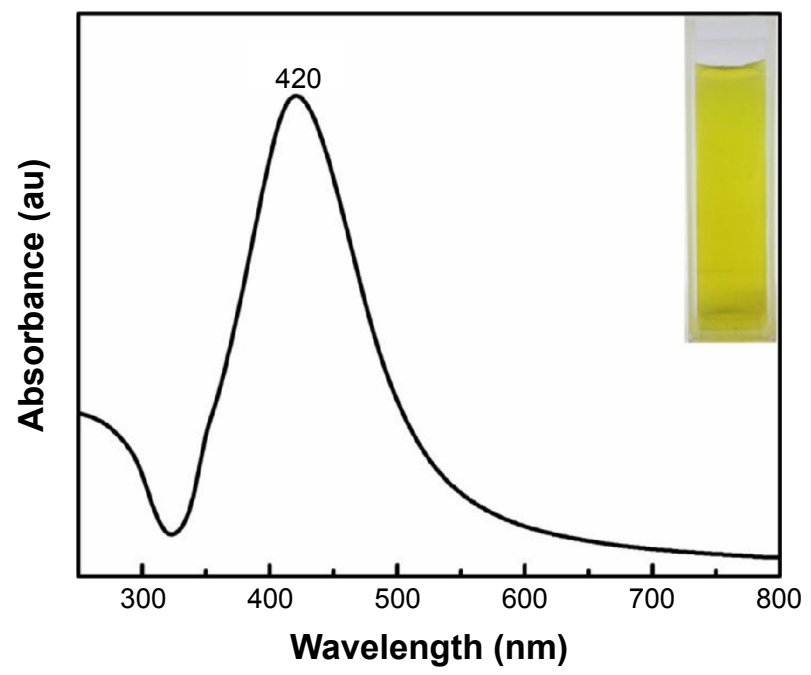

Figure S5 UV-vis absorption spectrum of bare AgNPs. Abbreviations: UV-vis, ultraviolet-visible; AgNPs, silver nanoparticles. 
tubing, 12,000-14,000 Da) and were stored in a sealed vessel protected from light.

The formation of AgNPs was confirmed through the plasmon absorption band at $420 \mathrm{~nm}$ (UV-Vis, Shimadzu
UV-1650PC spectrometer), and the morphology of the AgNPs was observed by TEM (Zeiss LIBRA 120 microscope, accelerating voltage of $120 \mathrm{kV}$ ).
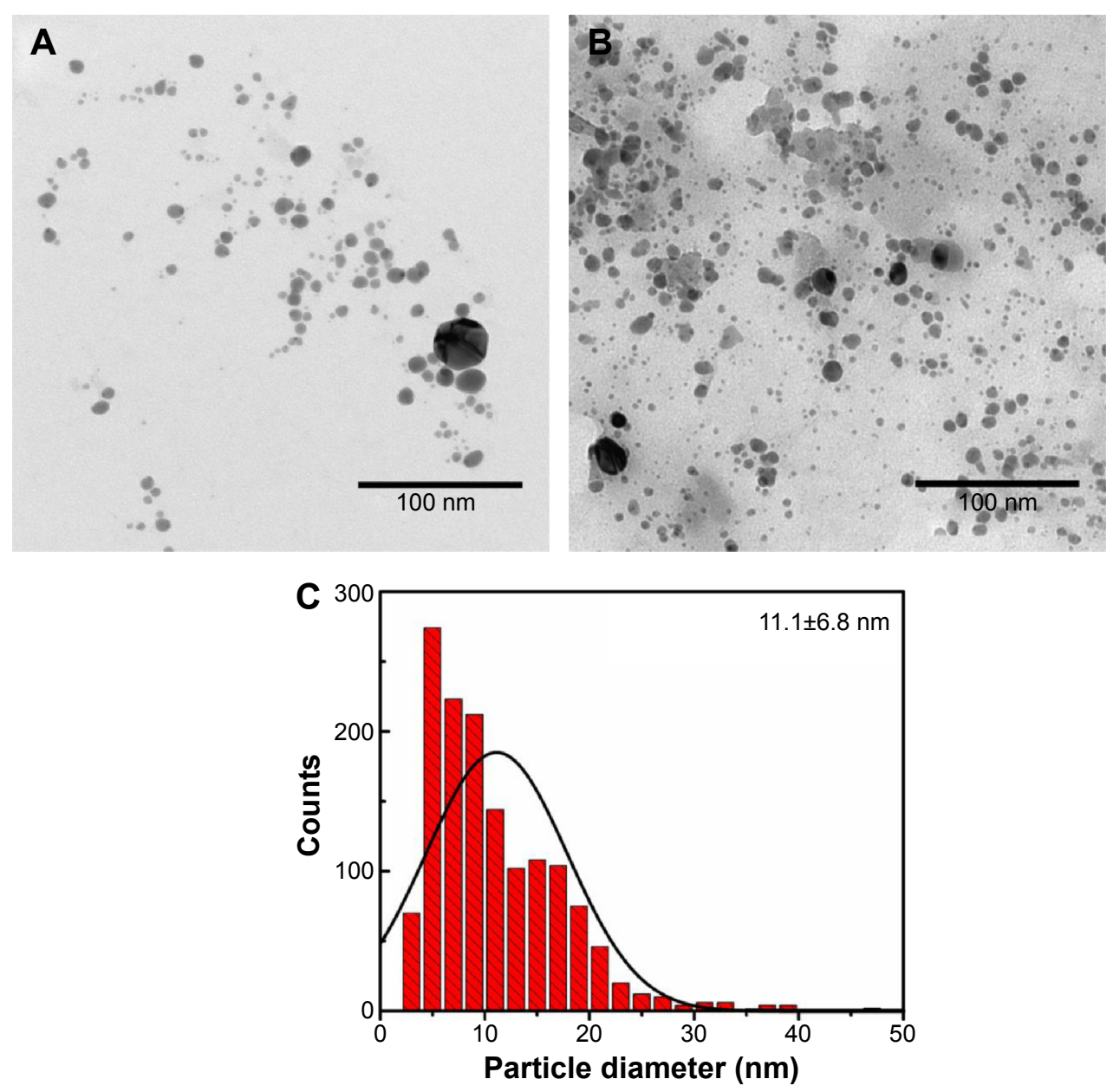

Figure S6 (A) and (B), TEM images of bare AgNPs. (C) Particle size distribution of AgNPs. The size distribution was calculated by counting more than 500 nanoparticles in several AgNP images, using ImageJ software.

Abbreviations: TEM, transmission electron microscopy; AgNPs, silver nanoparticles.

\section{Publish your work in this journal}

The International Journal of Nanomedicine is an international, peerreviewed journal focusing on the application of nanotechnology in diagnostics, therapeutics, and drug delivery systems throughout the biomedical field. This journal is indexed on PubMed Central, MedLine, CAS, SciSearch $\AA$, Current Contents ${ }^{\circledR} /$ Clinical Medicine,
Journal Citation Reports/Science Edition, EMBase, Scopus and the Elsevier Bibliographic databases. The manuscript management system is completely online and includes a very quick and fair peer-review system, which is all easy to use. Visit http://www.dovepress.com/ testimonials.php to read real quotes from published authors. 